Елизавета Викторовна Гусева

МГУ имени М. В. Ломоносова,

Филологический факультет

Кафедра русского языка для учащихся гуманитарных

факультетов

elviguseva@mail.ru

\section{Драгана Попович}

Университет города Нови-Сад

Философский факультет

Кафедра славистики

dragana.popovic@ff.uns.ac.rs
УДК 811.161.1'367.625:371(497.11) https://doi.org/10.18485/slavistika.2018.22.2.13 оригинални научни рад примљено 28.02.2018. прихваћено за штампу 04.10.2018.

\title{
ИЗУЧЕНИЕ РУССКИХ ГЛАГОЛОВ ДВИЖЕНИЯ В СЕРБСКОЙ АУДИТОРИИ НА РАЗНЫХ ЭТАПАХ
}

В статье рассматриваются основные трудности, возникающие при изучении русских глаголов движения сербскоговорящими учащимися. Делается краткий обзор некоторых учебных пособий, посвященных данной теме, а также рассматриваются дополнительные материалы, помогающие лучше освоить тему глаголов движения.

Ключевые слова: РКИ, глаголы движения, учебные пособия, дополнительные учебные материалы.

The article deals with the main difficulties encountered in the acquisition of Russian verbs of motion by Serbian-speaking students. A brief overview of some of the tutorials on the topic is provided, as well as additional materials that help students to master the topic of verbs of motion.

Key words: Russian as a foreign language, verbs of motion, grammar workbooks, additional educational materials.

О русских глаголах движения и трудностях усвоения этой системы иноязычными учащимися написано много статей, создано немало учебников, посвящённых именно этой теме, каждый год появляется большое количество новых работ: статей, методических разработок, диссертаций, учебников. Тем не менее, эта область остаётся одной из самых сложных и трудных даже для носителей близкородственных языков, имеющих довольно высокий уровень знания русского языка. У любого опытного преподавателя русского как иностранного есть свои любимые учебники и разработки, но в связи с огромным количеством материала можно потерять что-то полезное, а для начинающих преподавателей подготовка к занятию по теме «Глаголы движения» превращается в тяжёлое испытание.

Несмотря на то, что в сербском и русском языках система глаголов движения имеет общий источник, в сербском языке система претерпела очень большие изменения, вплоть до того, что уже не является системой противопоставленных значений (подробнее см. в (Гусева, Попович 2012)). В связи с этим ошибки в употреблении русских глаголов движения в речи сербскоговорящих учащихся - одни из самых частотных.

Проблемы, которые носители сербского языка испытывают при употреблении русских глаголов движения, являются результатом упрощения системы 
глаголов движения в сербском языке. В первую очередь это относится к употреблению русских бесприставочных глаголов движения. Несовпадение систем глаголов движения в двух языках заключается в отсутствии в современном сербском языке характерных для русской системы глаголов движения соотносимых глагольных пар, объединенных морфологическими и семантическими признаками, а тем самым и в отсутствии четкого противопоставления по признакам направленности / ненаправленности и повторяемости / неповторяемости. Одним из последствий упрощения системы глаголов движения сербского языка является и возможность широкого употребления глагола $u \hbar$. Поэтому работа над темой глаголов движения подразумевает выбор подходящей и качественной литературы. Речь идет о пособиях, ценность которых состоит в том, что в них даются систематизированные знания по теме глаголов движения и четко определяются типы движения (например, До леса мы шли вместе - однократное / неповторяющееся однонаправленное движение; До леса мы обычно или вместе - повторяющееся однонаправленное движение; Вчера мы ходили в лес - однократное / неповторяющееся двунаправленное движение; Летом мы часто ходили в лес - повторяющееся двунаправленное движение; Вчера мы долго ходили по лесу - однократное / неповторяющееся ненаправленное движение; Обычно мы долго ходили по лесу — повторяющееся ненаправленное движение (Юдина 2014: 9)).

Обычно учащиеся без особых проблем усваивают употребление бесприставочных глаголов движения в ситуациях: 1) неповторяющегося однонаправленного движения (До леса мы шлли вместе); 2) неповторяющегося ненаправленного движения (Вчера мы долго ходили по лесу); 3) повторяющегося ненаправленного движения (Обычно мы долго ходили по лесу); 4) повторяющегося двунаправленного движения (Летом мы часто ходили в лес). Употребление глаголов движения типа идти при обозначении неповторяющегося движения объясняется через следующие ситуации: Почему ты идёшь так медленно? Мы можем опоздать (движение происходит в момент речи); Я видел тебя утром около поликлиники. -Я шёл к зубному врачу (действие отнесено к опрёделенному моменту прошлого); Сегодня я ехала на занятия и читала журнал (движение служит фоном для другого, главного действия) (Юдина, Битехтина 2005: 15-16).

У сербскоговорящих учащихся чаще всего проблемы возникают при употреблении бесприставочных глаголов движения в ситуациях: 1) однократного двунаправленного движения (Вчера мы ходили в лес); 2) повторяющегося однонаправленного движения (До леса мы обычно шли вместе; Когда я шла на работу, я иногда встречала намего почтальона; Когда мы ехали куда-нибудь в автобусе, он всю дорогу что-нибудь читал) (Юдина 2014: 9, 11). Ситуации употребления глаголов движения типа идти при обозначении повторяющегося движения определяются следующим образом: 1) однонаправленное движение в контексте одновременных действий; главное действие происходит на фоне движения (Каждый раз, когда мы шли вместе, он начинал разговор на эту тему; Девушка всегда волновалась, когда шла на экзамен; Пока я ехал на работу, я обычно успевал просмотреть газету; От дома до работы я добираюсь час. Обычно я еду и читаю (в дороге я читаю); 2) однонаправленное движение в контексте последовательных действий; при обозначении начала повторяющегося дви- 
жения (Обычно, как только мы садились в вагон, поезд трогался. Мы ехали и читали или разговаривали; Раздавался звонок, и все или на перерьв) (Юдина, Битехтина 2005: 44-45).

Так как учащиеся регулярно связывают повторяющееся движение только с глаголами группы ходить, особый акцент делается на разнице между употре-

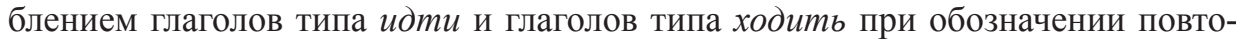
ряющегося движения: Я часто хожу к своим друзьям - Обычно я заканчиваю свои дела и иду в гости к своим друзьям; Каждый год я езжу на море - Каждый год, как только наступает лето, я еду на море (Муравьева 1980: 51-52). Таким образом, подчеркивается, что в контексте одновременных и последовательных действий использование глаголов группы ходить вместо глаголов группы идти недопустимо.

У сербскоговорящих учащихся проблемы могут возникнуть как при употреблении глаголов движения типа ходить для обозначения однократного комплексного движения, так и для обозначения способности, умения, склонности, возможности двигаться каким-либо образом: 1) Вчера я ходил в гости (был в гостях); Этим летом мы ездили на море (были на море); 2) Ребёнок уже большой, скоро начнёт ходить; Она прекрасно плавает и ездит на велосипеде; Врач разрешил больному ходить; Вам нужно больше ходить; Я уже летал на самолёте (Юдина, Битехтина 2005: 6).

Недоумение у учащихся вызывает и возможность употребления глаголов группы ходить при описании повторяющегося однонаправленного движения. Такое употребление возможно в предложениях, где речь идёт о движении как о единственном действии, ср. В университет мы ехали с Машей, а из университета домой я ехала одна (однократное однонаправленное движение); В университет мь обычно ехали с Машей, а из университета домой я ехала одна (повторяющееся однонаправленное движение); В университет мы обычно ездили с Машей, а из университета домой я ездила одна (повторяющееся однонаправленное движение). Данные ситуации объясняются следующим образом: «Однонаправленность движения и его повторяемость выражены средствами контекста, а глагол указы-

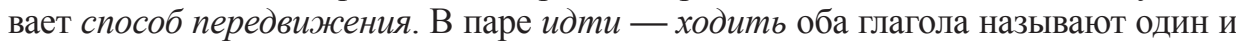
тот же способ передвижения. Поэтому оба этих глагола могут быть использованы при описании повторяющегося однонаправленного движения в предложениях, где речь идёт только об одном действии - о движении». Таким образом, глаголы

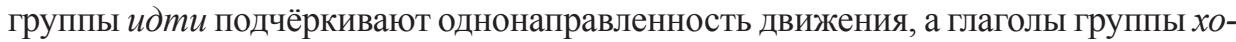
дить - его повторяемость (Юдина 2014: 22, 152).

В любом комплексном учебнике есть обязательно данная тема, но она настолько сложна, что часто требует особой, тщательной проработки. Кроме того, для лучшего усвоения потребуется использование и дополнительных материалов.

\section{Учебные пособия}

Рассмотрим некоторые учебные пособия, посвящённые конкретно теме глаголов движения

1. Богомолов А. Н., Петанова А. Ю. Приходите!.. Приезжайте!.. Прилетайте!.. СПб.: Златоуст, 2015. 104 страницы.

Учебник для базового уровня. Издаётся с 2008-го года в «Златоусте». Состоит

Славистика XXII/2 (2018) 
из таблиц и упражнений (так называемых «Программ»), к которым даны ответы в конце учебника. Значения бесприставочных глаголов движения представлены в виде простых схематических рисунков, с примерами и минимальным количеством пояснений, которые действительно подходят именно для начальных уровней изучения языка. Основные таблицы собраны в начале учебника, что облегчает использование его как справочника. Далее даются задания в виде простых тестов. Есть тест, посвящённый переносным значениям. Немного сложнее часть с текстами, очень интересна часть «Задания с рисунками».

2. Скворцова Г. Л. Глаголы движения - без ошибок. Москва: Издательство «Русский язык». Курсы, 2013. 136 страниц.

Этот учебник хорош тем, что его можно использовать не только, как сказано в аннотации, для имеющих базовый уровень, но и на более высоком уровне, так как в учебнике много лингвистических комментариев и объяснений, которые можно давать учащимся для самостоятельного изучения. Имеются и ключи к заданиям, но не ко всем. В книге есть и картинки, и схемы, и упражнения не только типа «вставить слово», но и творческие задания, а также много текстов (как больших, так и мини); тема «Глаголы движения в переносном значении» не представлена с объяснениями, но дано много текстов. Неплохо рассмотрены глаголы с приставкой ПО-. Все схемы и таблицы даны в общем порядке с упражнениями, так что в качестве «быстрого справочника» его использовать не очень удобно, но такой способ расположения помогает разобраться во многих тонкостях, так как на каждое отдельное «подзначение» сразу после объяснения даются отдельные упражнения.

3. Муравьёва Л. С. Глаголы движения в русском языке. Москва: Издательство «Русский язык», 1980. 240 страниц.

Это целая серия книг для людей, говорящих на определённых языках. Существуют варианты для англоговорящих, франкоговорящих, испаноговорящих и говорящих на немецком языке. Основное отличие этих учебников в том, что все комментарии и задания даны на языке учащегося. В пособии рассматриваются все аспекты глаголов однонаправленного и разнонаправленного движения, глаголов с приставками и без приставок и т. д. Пособие делится на две части. Первый раздел - упражнения, небольшие тексты, диалоги, шутки. Второй раздел содержит тексты и рисунки для развития навыков устной речи. Сразу бросается в глаза большое количество иллюстраций. Если сравнивать с учебником Скворцовой, то здесь больше заданий с иллюстрациями, помогающими ещё лучше понять особенности значения глаголов движения. Но упражнения похожи: и типа «вставить слово», и творческие. Кроме того, в конце книги даются очень подробные и полезные грамматические таблицы и ключ к наиболее трудным упражнениям. В целом, учебник можно использовать на более высоких уровнях (по сравнению с предыдущим).

4. Юдина Л. П. Идти или ходить? Глаголы движения в речи. Москва: Издательство «Русский язык». Курсы, 2014. 200 страниц.

Учебник хоть и предлагается для владеющих базовым уровнем, но без специального «фильтра» на начальных этапах будет тяжеловат. Материал разбит на 10 «Занятий», в которые входят упражнения (не тестового плана, больше всего - творческие задания), очень мало иллюстраций и таблиц. В конце учебника есть приложения в виде материалов для контроля и консультаций (реально 
— просто тексты с пропущенными ГД), а также ключи и очень подробные комментарии к занятиям. То есть этот учебник легко использовать и начинающему преподавателю, и при самостоятельном изучении языка.

5. Юдина Л. П., Битехтина Г. А. Глаголы движения: Устные упражнения с комментариями. Москва: Издательство Московского университета, 2005. 136 страниц увеличенного формата.

Это переработка более старого учебника («Устные тренировочные упражнения по теме «Глаголь движения»», 1976). Пожалуй, самый академический учебник. Каждой группе глаголов (по значению, с разными приставками) посвящён свой раздел с комментариями и упражнениями. Все объясняется подробно, даны таблицы, задания требуют творческого подхода. Конечно, данный учебник нельзя использовать в группах начальных уровней. Но он может стать прекрасным справочником для преподавателя или самоучителем для продвинутых учащихся.

\section{Дополнительные материаль}

В дополнение к учебникам полезно использовать и другие материалы. Это не только поможет облегчить процесс освоения материала с психологической точки зрения, но и даст возможность увидеть глаголы движения в их «реальной жизни».

Самыми удобными, конечно, являются видеоматериалы, ведь именно они лучше всего иллюстрируют динамическую сущность, которая и обозначается глаголами. Вообще, можно использовать почти любой фильм. Рано или поздно в нем кто-нибудь куда-нибудь пойдёт, полетит, побежит, что-нибудь понесёт и повезёт. Но удобнее всего фильмы короткие, наполненные большим количеством разных типов движения. Например, короткометражные фильмы 1961 года режиссёра Леонида Гайдая «Пёс Барбос и необычный кросс» и «Самогонщики». В этих фильмах нет звучащего текста (кроме песни в «Самогонщиках»), но очень много движения. Их можно использовать для разных уровней. На начальных они могут быть иллюстрацией к объяснениям преподавателя, а на продвинутых - видеорядом для описания учащимися.

Короткие мультфильмы тоже удобны при изучении глаголов движения. Здесь ещё больше вариантов и разнообразия. Вот четыре примера.

1. «Как львёнок и черепаха пели песню» (реж. Инесса Ковалевская, 1974). Мультфильм хорош для начального уровня: в нем чёткий текст и можно давать задание на узнавание ГД. Песню из этого мультфильма учащиеся любого возраста, пола и национальной принадлежности сразу начинают подпевать.

2. «Кто получит приз» (реж. Вячеслав Котёночкин, 1979). В этом мультфильме показаны соревнования по бегу в лесу (в котором победил медвежонок Миша, за что и стал символом Олимпийских игр), его хорошо брать при изучении приставочных ГД (можно дать задание описать происходящее).

3. «Крылья, ноги и хвосты» (реж. Александр Татарский и Игорь Ковалёв, 1985). Здесь текст звучит не очень понятно, по этому мультфильму хорошо давать задание пересказать происходящее и восстановить текст (на более высоком уровне).

4. «Летучий корабль» (реж. Гарри Бардин, 1979) может быть интересен старшим школьникам и студентам, потому что это сказка о любви. Кроме того, это, практически, мюзикл. «Концентрация» глаголов движения в тексте этого муль-

Славистика XXII/2 (2018) 
тфильма не очень большая, но при пересказе содержания потребуется большое количество разнообразных глаголов.

Песни всегда были хорошим вариантом для изучения языка. Например, для начальных уровней подойдёт задание по песням в исполнении Михаила Боярского («Всё пройдёт» и «Сяду в скорый поезд»): прослушать песню, вставить в текст пропущенные слова, в правом столбике выписать эти слова, восстановить инфинитивы и бесприставочные глаголы, от которых они образованы. По второй песне на более высоких уровнях можно дать задание объяснить, что там такое произошло (не очень простой вопрос). Многим будет интересна песня Владимира Высоцкого «Лежит камень в степи», особенно взрослым учащимся. В этой песне всего 10 словоформ 6-ти глаголов движения (1 - в переносном значении).

Конечно, интересны и просто стихи, которых можно найти много, в зависимости от аудитории, уровня, общей темы. Тексты из газет представляют реальный современный язык. Оживляют процесс и диалоги, разыгранные по ролям. Особенно они хороши тогда, когда показывают реальную, «живую» разговорную речь, а не книжные варианты. Молодым будет интересно проговорить речь молодых, с включением разговорных фраз, жаргонизмов и даже просторечий. На их материале можно ещё точнее разграничить разные значения глаголов движения, проиллюстрировать реальную частотность их использования в живой речи. Использовать это можно для любых уровней студентов, варьируя задания.

Начинающего русскоязычного преподавателя может обмануть языковое сходство (наличие и одинаковость) глаголов движения в русском и сербском языках. Но изучение данной темы в сербской аудитории сталкивается с серьезными трудностями из-за несовпадения систем и требует тщательной проработки с использованием не только специальных учебников, но и дополнительных материалов, помогающих носителям сербского языка вникнуть в суть правил выбора глаголов движения в русском языке.

\section{Использованная литература}

Богомолов, Андрей Н., Анна Ю. Петанова. Приходите!.. Приезжайте!.. Прилетайте!.. СПб.: Златоуст, 2015.

Гусева, Елизавета В., Драгана Попович. «Сербские глаголы движения: система как источник ошибок при изучении русского языка как иностранного». Язык, литература, культура: Актуальные проблемы изучения и преподавания: Сборник научных и научно-методических статей. Выпуск 7. М.: МАКС Пресc, 2012. С. 273-289.

Муравьёва, Лариса С. Глаголы движения в русском языке. Москва: Издательство «Русский язык», 1980.

Скворцова, Галина Л. Глаголы движения — без ошибок. Москва: Издательство «Русский язык». Курсы, 2013.

Юдина, Лия П. Идти или ходить? Глаголы движения в речи. Москва: Издательство «Русский язык». Курсы, 2014.

Юдина, Лия П., Галина А. Битехтина. Глаголы движения: Устные упражнения с комментариями. Москва: Издательство Московского университета, 2005.

Јелизавета В. Гусева, Драгана Поповић 
Јелизавета В. Гусева, Драгана Поповић

\section{РУСКИ ГЛАГОЛИ КРЕТАҢА НА РАЗЛИЧИТИМ НИВОИМА УЧЕњА У СРПСКОЈ ГОВОРНОЈ СРЕДИНИ}

\section{Резиме}

У раду се указује на основне проблеме с којима се сусрећу говорници српског језика при усвајању правила употребе руских глагола кретања. У вези с тим даје се кратак преглед литературе која омогућава ефикаснију обраду и лакше усвајање теме глагола кретања. Дата литература у раду је представљена у односу на нивое учења језика. Прилаже се и различит додатни материјал који доприноси бржем усвајању руског система глагола кретања и утврђивању стеченог знања.

Кључне речи: руски језик као страни, глаголи кретања, приручници, додатни наставни материјал. 